Malega, P., Rudy, V., Kovac, J., \& Kovac, J. (2019). The Competitive Market Map as the Basis for an Evaluation of the Competitiveness of the Slovak Republic on an International Scale. Journal of Competitiveness, 11(4), 103-119. https://doi.org/10.7441/joc.2019.04.07

\title{
THE COMPETITIVE MARKET MAP AS THE BASIS FOR AN EVALUATION OF THE COMPETITIVENESS OF THE SLOVAK REPUBLIC ON AN INTERNATIONAL SCALE
}

- Peter Malega, Vladimir Rudy, Juraj Kovac, Jozef Kovac

\begin{abstract}
This research paper is focused on the competitive market map as the key tool for classifying enterprises (or countries) in terms of their shares and market positions, as well as on the competitiveness of the Slovak Republic at the international level through the GCI index. This article has three main sections, with first concentrating on a literature review of the issue of competitiveness as the crucial term in this paper. The second main part deals with the competitive market map, in which numerous equations can be found to aid in understanding the problem of competition as a whole. This part also contains a section on the matrix compilation of the competitive market map. The third main section of the article deals with competitiveness measurement in the global world with the emphasis on the Slovak Republic. Here an evaluation of countries through the Global competitiveness index as well as a SWOT analysis of enterprise competitiveness in the Slovak Republic is presented. The Slovak position competitiveness ranking of 41st shows an improvement over previous years, although several challenging issues remain to be resolved by the national government in the near future. The main goal of this article is to evaluate the competitiveness of Slovak Republic on the international scale based on the competitive market map, a tool which is used as the basis for an evaluation of the competitive position of a particular firm as well as that of a particular nation.
\end{abstract}

Keywords: competitiveness, competitive market map, competitiveness measuring, Slovak Republic JEL Classification: O11, O52, P20, P51

Received: May, 2019

1st Revision: October, 2019

Accepted: October, 2019

\section{INTRODUCTION}

The goal of any enterprise operating on the market is to meet customer needs more effectively than its competitors, and to thus gain a more favourable market position, i.e. to improve its competitive advantages. The life of an enterprise depends on its ability to compete in the ever-changing competitive market, attract new customers, and ensure a more competitive market position (Straka, 2016). 
Nevertheless, the current market environment does not create the best conditions for implementing all business plans and strategies, with one of these mitigating factors being that of consumer mistrust (Zavadsky, 2019).

Being competitive means exploiting all the opportunities offered by the market through a wellchosen competitive strategy to gain a competitive advantage over the opponent.

\section{THEORETICAL BACKGROUND}

Even after decades of research, no clear and agreed-upon definition of "competitiveness" has emerged in the literature. Very often, the definition of competitive ability comes to the fore at the company level. Companies are competitive if they are able to sell the products they manufacture or otherwise create. From an expert point of view, it is not possible to consider a firm as competitive merely because it is able to sell its products. At least two additional questions must be addressed: At what price? With how much profit? If it is assumed that the company's goal is to maximize financial returns, even a high profit margin may not be an indicator of a company's high competitiveness (Malega, 2018).

The term competitiveness is a concept of economic theory with several synonymous terms in the literature, e.g. competitive ability, competitive prowess, competitive performance, and competitive strength. In general terms, it follows from the definitions put forth that competitiveness entails a long-term ability to acquire, maintain and increase market position, a situation influenced by many quantitative and qualitative factors (Malega, 2017). In general, three basic levels of competitiveness can be distinguished (Mihok et al., 2006):

- Competitiveness at national, resp. international level

- Competitiveness at sector level

- Competitiveness at company level

The word competitiveness derives from the Latin "petere," i.e. ask, seek, pursue, desire, attack, with the prefix " $\mathrm{co}(\mathrm{n})-$ " indicating together. After this initial understanding of this crucial term, many other denotations of the concept have emerged. Competitiveness in the sense of economic activity does not have such an old research history, with the first articles originating in 1970 and continuing to the present day.

Many definitions the terms are similar, but each presents a different emphasis. Competitiveness has been described as the capacity of countries, regions and organizations to insure profitability as the precondition for high wages (Bobba et al., 1971). Competitiveness is the limit of a division, business or branch to structure and sell its products at a cost and level of quality as well as with other influential factors that make these products more alluring than the parallel attributes of the merchandise offered by the competition (Flejterski, 1984). Competitiveness is our capacity to create goods and services that meet the trial of universal challenge while citizens can enjoy living standards that are both rising and feasible (D’Andrea Tyson, 1992).

In the literature, the concepts of real and nominal competitiveness can be found. The first term requires the transparency and reasonableness of business sectors, the quality and advancement 
of produced goods, as well as functional governmental regulation as a starting point, after which the improvement of the living standards of citizens can be ensured. Along these lines, the real level of competitiveness is the possibility of national enterprises to maintain a free and reasonable market of products and services that meet the prerequisites of both residential and remote markets along with the synchronous development of genuine salary. Nominal competitiveness can be accomplished by a specific government strategy creating a macroeconomic situation for domestic firms through direct state endowments and compensation limitation. In this way, the first term is conceivable only if national organizations can adequately configurate, produce products and sell them at costs and levels of quality that meet the prerequisites of all outside and inside clients (Kulikov, 2000).

If competitiveness is to have any significance at all, it is simply one more approach to express productivity. The capacity of a nation to increase its expectations for everyday comforts depends essentially on its capacity to raise its productivity. Competitiveness is an "inane" word when connected to national economies (Krugman, 1995). Competitiveness is a political and financial idea that influences the military, political and logical capability of the nation, and it is a basic factor in the overall position of the nation in the global political economy (Rapkin et al., 1995).

A firm's competitiveness entails its capacity to create and sell items and administrations of predominant quality as well as to seek lower costs than its local and worldwide contenders are able to. Within a firm, competitiveness has for quite some time meant being able to show a profit, i.e. the capacity to remunerate workers and bring better returns than do its business rivals (Buckley et al., 1988).

The competitiveness of an organization comes through the adjustment of its items to the market as well as sometimes conflicting prerequisites, namely manipulating item range, quality and cost as well as securing the best possible sales channels and strategies for advancement (Adamkiewicz-Drwiłło, 2002).

The competitiveness of a business is its offer in the focused market (Ambastha \& Momaya, 2004).

A firm's competitiveness is its financial quality in comparison to its opponents in the worldwide market, where items, services, individuals and changes move uninhibitedly in spite of geographical limits (Gulev \& Dukaric, 2010).

Further focusing on competitiveness at national level, national competitiveness is a nation's capacity to make, produce, and circulate items in worldwide exchange while acquiring rising profits in ratio to its assets (Scott \& Lodge, 1985).

In the enhancement of its competitiveness, a country has to focus on the living standards of the population, thus to define competitiveness as the ability to sustain an acceptable level of living growth in the global economy through fair distribution (Hickman, 1992).

According to Krugman (1995), improving the standard of living can only be ensured through increasing productivity.

The main significant idea of competitiveness at the national dimension is national efficiency. Competitiveness is a capacity of an economy to give its inhabitants a rising way of life and a high work on a practical premise (Porter, 1990). 
A country's competitiveness is the measure of how much it can (under free and equitable conditions) produce products or services meeting the trial of universal markets, while maintaining and extending the genuine earnings of its people over the long term (Barker \& Köhler, 1998).

The most natural definition of competitiveness for a nation is the securing of many world markets for its items. This makes competitiveness in principle a zero-sum game, since one nation's increase comes at the detriment of others (Porter et al., 2008).

External or international competitiveness is the capacity to trade the products and services readily available in the home nation for goods and services from another country that are rare in the home nation (Altomonte et al., 2012).

A competitive economy is an economy with a reliably high rate of profitability development. Competitiveness relies upon the generation of a strong national industrial economy as fuelled by SMEs. To be competitive, the EU must outpace its rivals in terms of research. In addition, the advancement of IT, entrepreneurship, internal competition among firms, as well as the level of education, training and instruction and preparing is essential. The competitiveness of a country is the capacity of an economy to furnish its people with high and rising living standards based on high rates of employment in practical occupations (European Competitiveness and Industry, 2017).

Competitiveness is the capacity of countries to create and maintain an environment in which companies can contend. It is additionally the capacity of an economy to deal with the totality of its resources and abilities, and in this way to expand the prosperity of its people. Competitiveness is the capacity to maintain a persistent development rate of genuine per capita salary, which can be estimated by the pace of development of its GDP per capita at steady costs (The Global Competitiveness Report, 2018).

High global competitiveness index of a country favors the increase of opportunity entrepreneurs (Crecente-Romero, et al., 2019).

Gkypali et al. (2019) stated that the level of competitiveness is not considered at a given state with an implied equilibrium; rather, it is perceived as a perpetually forming and adjusting mechanism from a constantly developing set of competencies, capabilities, and technological innovations.

Competitiveness, respectively its level is proportional to the level of production efficiency in the country. (Salas-Velasco, 2019).

Fifekova et al. (2019) stated that the notion of competitiveness itself evolved from a microeconomic feature of the exporting firm to the broader concept of global competitiveness, which characterizes the national economy.

\section{RESEARCH OBJECTIVE, METHODOLOGY AND DATA}

The role of the competitive map of the market, which is crucial for competitiveness evaluation, is to classify enterprises (or countries) in terms of their shares and market positions. So, on the market, we can distinguish:

- Market leaders - significantly prospering on the market,

- Market outsiders - having a weak position. 
The scheme of distributing the market shares of competitors in terms of their production in mathematical statistics is defined as the so-called log normal, as shown in Figure 1.

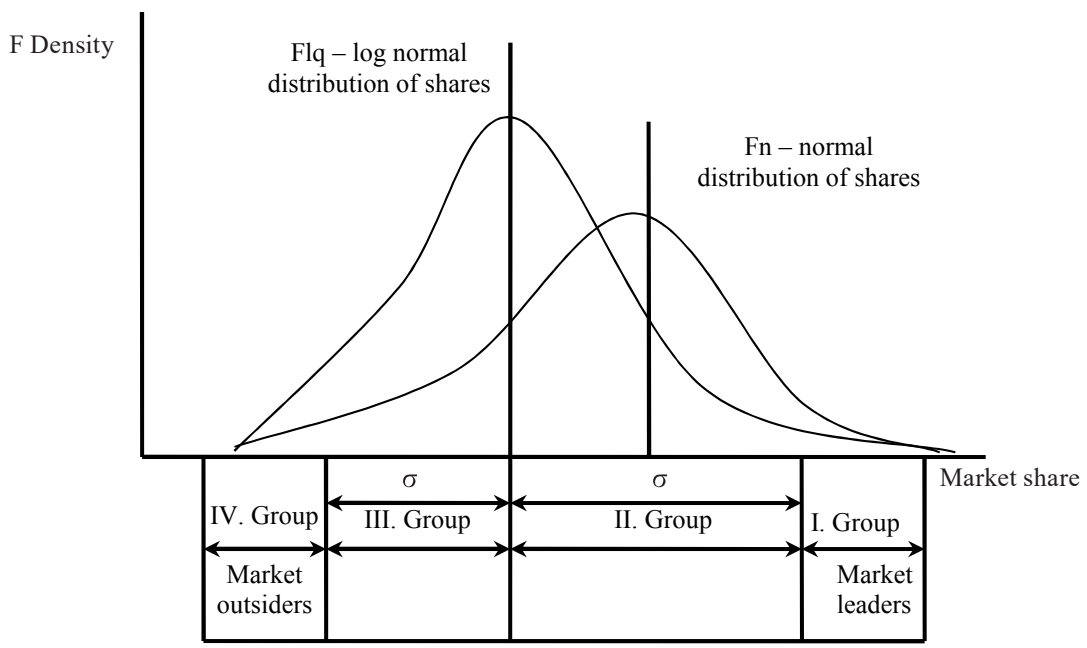

Fig. 1 -Distribution of the market shares of competitors in terms of their production. Source: own research

$\sigma_{1}$ shows the interval of weak and $\sigma_{2}$ the interval of strong competitive positions. The enterprise group IV shows outsiders and I. indicates leaders.

When distributing enterprises, we proceed as follows:

- Group 1 - market leaders $\left[\mathrm{P}_{\mathrm{pr}}+\sigma_{2}, \mathrm{P}_{\max }\right]$,

- Group 2 - having a strong competitive position $\left[\mathrm{P}_{\mathrm{pr}}, \mathrm{P}_{\mathrm{pr}}+\sigma_{2}\right]$,

- Group 3 - having a weak competitive position $\left[\mathrm{P}_{\mathrm{pr}}-\sigma_{1}, \mathrm{P}_{\mathrm{pr}}\right]$,

- Group 4 - market outsiders $\left[\mathrm{P}_{\min }, \mathrm{P}_{\mathrm{pr}}-\sigma_{1}\right]$.

where:

$\mathrm{P}$ - distribution of the market shares

$\mathrm{P}_{\mathrm{pr}}$ - average arithmetic significance of the shares of all shares

$\mathrm{P}_{\mathrm{pr}}=1 / \mathrm{n}$

$\mathrm{P}_{\min }-$ minimal importance of the market shares

$\mathrm{P}_{\min }=\min \left\{\mathrm{P}_{\mathrm{i}}\right\}, \mathrm{i}=1, \ldots, \mathrm{n}$

$\mathrm{P}_{\max }$ - maximal importance of the market shares

$\mathrm{P}_{-\max }=\max \left\{\mathrm{P}_{\mathrm{i}}\right\}, \mathrm{i}=1, \ldots, \mathrm{n}$

$\sigma_{1}\left(\sigma_{2}\right)$ - Average quadratic deviations of the market shares of enterprises, while

$\mathrm{P}_{\mathrm{i}} \geq \mathrm{P}_{\mathrm{pr}}$ 
$\sigma_{1}=\sqrt{\left(\frac{1}{\mathrm{~m}_{1}}\right) \times \sum\left(\mathrm{P}_{\mathrm{s}}-\mathrm{P}_{\mathrm{pr}}\right)^{2}}, \mathrm{~s}=1, \ldots ., \mathrm{m}_{1}$

$\sigma_{2}=\sqrt{\left(\frac{1}{n-m_{1}}\right) \times \sum\left(P_{t}-P_{p r 2}\right)^{2}}, t=1, \ldots ., n-m_{1}$

while:

$m_{1}\left(n-m_{1}\right)$ - number of enterprises that have $P_{s}<P_{p r}\left(P_{t} \geq P_{p r}\right)$

$\mathrm{P}_{\mathrm{s}}\left(\mathrm{P}_{\mathrm{t}}\right)$ - market shares of enterprises that have $\mathrm{P}_{\mathrm{s}}<\mathrm{P}_{\mathrm{pr}}\left(\mathrm{P}_{\mathrm{t}} \geq \mathrm{P}_{\mathrm{pr}}\right)$

$\mathrm{P}_{\mathrm{pr} 1}, \mathrm{P}_{\mathrm{pr} 2}$ - average arithmetic significance of the market shares of enterprises for which is $\mathrm{P}_{\mathrm{s}}<\mathrm{P}_{\mathrm{pr}}$ $\left(\mathrm{P}_{\mathrm{t}} \geq \mathrm{P}_{\mathrm{pr}}\right)$

$\mathrm{P}_{\mathrm{pr} 1}=1 / \mathrm{m} 1 \times \sum \mathrm{P}_{\mathrm{s}}, \mathrm{s}=1, \ldots, \mathrm{m} 1$

$\mathrm{P}_{\mathrm{pr} 2}=1 /(\mathrm{n}-\mathrm{m} 1) \times \sum \mathrm{P}_{-\mathrm{t}}, \mathrm{t}=1, \ldots, \mathrm{n}-\mathrm{m} 1$

$\mathrm{T}_{\mathrm{i}}=1 / \mathrm{Y} \times\left(\mathrm{P}_{\text {it }}-\mathrm{P}_{\text {ito }}\right) / \mathrm{P}_{- \text {ito }} \times 100 \%$

$\mathrm{T}_{\mathrm{i}}$ - growth rate of the share on the market of $\mathrm{i}$-enterprise in $\%$

$\mathrm{P}_{\text {it }}\left(\mathrm{P}_{\mathrm{ito}}\right)$ - market share of $\mathrm{i}$-enterprise in a certain period $\mathrm{t}\left(\mathrm{t}_{\mathrm{o}}\right)$ in $\%$

$\mathrm{Y}$ - number of years in the period under review

For evaluation of the level of competitive environment on the market, there are four groups:

- Group 1 - competitive environment is rapidly improving $\left[\mathrm{T}_{\mathrm{pr}}+\sigma, \mathrm{T}_{\max }\right]$,

- Group 2 - competitive environment is rapidly improving $\left[\mathrm{T}_{\mathrm{pr}}, \mathrm{T}_{\mathrm{Ppr}}+\sigma\right]$,

- Group 3 - a competitive position is getting worse $\left[\mathrm{T}_{\mathrm{pr}}-\sigma, \mathrm{T}_{\mathrm{pr}}\right]$,

- Group 4 - a competitive position is getting worse $\left[\mathrm{T}_{\min }, \mathrm{T}_{\mathrm{pr}}-\sigma\right]$.

$\mathrm{T}_{\mathrm{pr}}=\left\{\frac{\sum \mathrm{M}_{\mathrm{it}}}{\mathrm{M}_{\mathrm{ito}}}-1\right\} \times 100 \%, \mathrm{i}=1, \ldots ., \mathrm{n}$

or

$\mathrm{T}_{\mathrm{pr}}=\left\{\frac{\sum \mathrm{M}_{\mathrm{it}} \times \mathrm{C}_{\mathrm{it}}}{\mathrm{M}_{\mathrm{ito}} \times \mathrm{C}_{\mathrm{jto}}}-1\right\} \times 100 \%, \mathrm{j}=1, \ldots ., \mathrm{n}_{\text {to }}$

where:

$\mathrm{M}_{\mathrm{it}}\left(\mathrm{M}_{\mathrm{jto}}\right)$-products quantity of the group of goods under review, which is implemented by ienterprise in the period $\mathrm{t}\left(\mathrm{t}_{\mathrm{o}}\right)$

$\mathrm{C}_{\mathrm{it}}\left(\mathrm{C}_{\mathrm{jto}}\right)$ - price of products that is implemented by i-enterprises in the period $\mathrm{t}\left(\mathrm{t}_{\mathrm{o}}\right)$

$n\left(n_{t o}\right)$ - number of enterprises in the examined goods market in the period $t\left(t_{o}\right)$

$\mathrm{T}_{\min }\left(\mathrm{T}_{\max }\right)-$ minimum (maximum) growth rate of the market share

$\mathrm{T}_{-\min }=\min \left\{\mathrm{T}_{\mathrm{ii}}\right\}, \mathrm{i}=1, \ldots ., \mathrm{n}$

$\mathrm{T}_{-\max }=\max \left\{\mathrm{T}_{\mathrm{ii}}\right\}, \mathrm{i}=1, \ldots, \mathrm{n}$

The average quadratic deviation is calculated as follows:

$\sigma_{1}=\sqrt{\left(\frac{1}{n}\right) \times \sum\left(\mathrm{T}_{\mathrm{i}}-\mathrm{T}_{\mathrm{pr}}\right)^{2}}, \mathrm{t}=1, \ldots, \mathrm{n}$ 
The indicators of the market share stability $\left(\mathrm{S}_{\mathrm{i}}\right)$ divide enterprises within each group and are calculated as follows:

$\mathrm{S}_{\mathrm{i}}=\left(\mathrm{M}_{\mathrm{i}}-\mathrm{M}_{\mathrm{ik}}\right) / \mathrm{K}_{\mathrm{i}}$

where:

$\mathrm{M}_{\mathrm{i}}$ - total amount of goods that are processed by the e-enterprise,

$\mathrm{M}_{\mathrm{ik}}$ - amount of goods of $\mathrm{i}$-enterprise that was bought by consumers for the first time.

The above relationships summarize the most important information needed to compile a matrix of the competitive market map creation, as shown in Table 1. From Table 1, it is possible to get 16 types of enterprises. According to this matrix, the enterprises of the first group (leaders) are best placed, while the worst ones (outsiders) are placed sixteenth.

Tab. 1 - Matrix compilation of the competitive market map. Source: own research

\begin{tabular}{|c|c|c|c|c|c|}
\hline & & & Classific & ion scale & \\
\hline & Market share $\left(\mathrm{P}_{\mathrm{i}}\right)$ & 1 & 2 & 3 & 4 \\
\hline & $\begin{array}{l}\text { rowth rate of the market } \\
\text { share }\left(\mathrm{T}_{\mathrm{i}}\right)\end{array}$ & $\begin{array}{l}\text { Market } \\
\text { leaders }\end{array}$ & $\begin{array}{l}\text { Enterprises } \\
\text { with a strong } \\
\text { competitive } \\
\text { position }\end{array}$ & $\begin{array}{l}\text { Enterprises } \\
\text { with a weak } \\
\text { competitive } \\
\text { position }\end{array}$ & $\begin{array}{c}\text { Market } \\
\text { outsiders }\end{array}$ \\
\hline & & $\begin{array}{c}{\left[\mathrm{P}_{\mathrm{pr}}+\sigma_{2},\right.} \\
\left.\mathrm{P}_{\max }\right]\end{array}$ & {$\left[\mathrm{P}_{\mathrm{pr}}, \mathrm{P}_{\mathrm{pr}}+\sigma_{2}\right]$} & {$\left[\mathrm{P}_{\mathrm{pr}}-\sigma_{1}, \mathrm{P}_{\mathrm{pr}}\right]$} & {$\left[\mathrm{P}_{\min }, \mathrm{P}_{\mathrm{pr}}-\sigma_{1}\right]$} \\
\hline 1 & $\begin{array}{l}\text { Enterprises with a rap- } \\
\text { idly improving competi- } \\
\text { tive position }\left[\mathrm{T}_{\mathrm{pr}}+\sigma \text {, }\right. \\
\left.\mathrm{T}_{\max }\right]\end{array}$ & 1 & 5 & 9 & 13 \\
\hline 2 & $\begin{array}{c}\text { Enterprises with an } \\
\text { increasing competitive } \\
\text { position }\left[\mathrm{T}_{\mathrm{pr}}, \mathrm{T}_{\mathrm{pr}}+\sigma\right]\end{array}$ & 2 & 6 & 10 & 14 \\
\hline 3 & $\begin{array}{c}\text { Enterprises with a } \\
\text { worsening competitive } \\
\text { position }\left[\mathrm{T}_{\mathrm{pr}}-\sigma, \mathrm{T}_{\mathrm{pr}}\right]\end{array}$ & 3 & 7 & 11 & 15 \\
\hline 4 & $\begin{array}{l}\text { Enterprises with a } \\
\text { rapidly worsening com- } \\
\text { petitive position }\left[\mathrm{T}_{\mathrm{min}}\right. \\
\left.\quad \mathrm{T}_{\mathrm{pr}}-\sigma\right]\end{array}$ & 4 & 8 & 12 & 16 \\
\hline
\end{tabular}

The main goal of this paper is to evaluate Slovak Republic competitiveness on an international scale based on the competitive market map, which can be stated as the basis for evaluation of firm's competitive position, respectively nation's competitive position. 
The secondary goals can be set as follows:

- The analysis of the Slovak Republic competitiveness based on GCI index.

- Identification of the biggest obstacles that decrease the level of competitiveness in the Slovak Republic.

- Creation of the SWOT analysis of enterprises competitiveness in the Slovak Republic.

- Identification of the most important factors of the Slovak enterprises competitiveness as the basis for potential future evaluation.

\section{RESULTS AND DISCUSSION}

World Economic Forum (WEF) has carried out its evaluation since the late 1980s. This evaluation reflects the new factors that are connected with GCI and other factors of WEF. This evaluation gives anyone relevant information about the situation in particular state from the economic view as well as comparisons with situations in other states. To evaluate the state, the is constructed the overall index and the grades of countries development in terms of competitiveness are defined. If we analyse the results of the Slovak Republic since 2010, we will find out that space for business is improving but there are also many problem areas.

The Global Competitiveness Report can be rated as the world's No. 1 in the competitiveness evaluation. It is a complex evaluation that helps anyone to rate the national economic environment.

WEF through GCI performs the competitiveness measurement. The GCI index is based on 12 pillars of competitiveness. These pillars are in Figure 2.

Slovakia's position was deteriorating year by year since 2009. Thirteen years ago, the Slovak Republic placed was around 40th, which was quite good and it was a comparable position to other Visegrad Four countries (Hungary and the Czech Republic), but it was better than Poland. Those years, there were many new foreign investments that increased the position of Slovakia in the competitiveness ranking.

In the years 2008 - 2009, of the Slovak Republic the competitiveness decreased and after the year 2009, we recorded the biggest decrease in the Slovak history and the result was that the Slovak Republic dropped to the 80th position in 2013. In 2014 and 2015, Slovakia's competitiveness improved, up to 67th place in 2015. In 2106, Slovakia was on 65th place and in 2017, on 59th place. In 2018, the country scores were calculated using a new methodology. There was first used socalled Global Competitiveness Indicator 4.0 (GCI 4.0), which was conditioned by the emergence of new fundamental changes in the functioning of national economies withformation of the Fourth Industrial Revolution (4IR). It clarifies the emerging set of productivity-critical factors, provides a tool to evaluate them and captures the determinants of long-term growth. In addition to the change in methodology, the total number of countries evaluated also increased from 137 to 140 . These changes are such fundamental evaluation reforms that do not allow us to compare the results with the previous period. At the same time, since 2014, Slovakia's position has been 
constantly improving. In the last ranking, Slovakia recorded a shift from 59th to 41st among the 140 evaluated economies within this ranking.

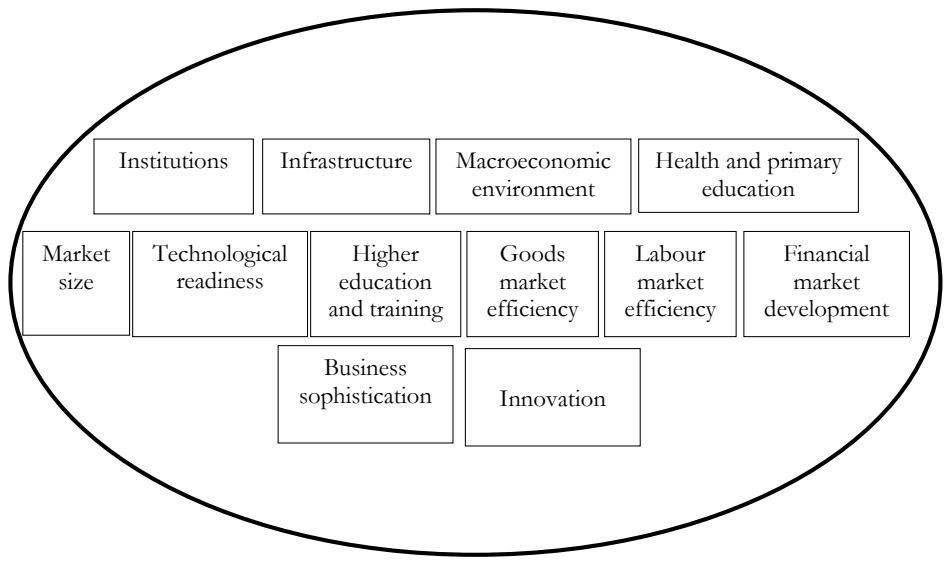

Fig. 2 - Pillars of GCI index. Source: The Global Competitiveness Report 2018. (2018).

More important than the position in the rankings is the improvement of the individual sections evaluated (quality of public institutions, adoption of information and communication technologies, financial system and innovation capabilities). However, the Slovak Republic needs to continue working in the areas where results are behind the EU average (population health and work experience, workforce skills, labour market efficiency or business dynamics). The Slovak Republic competitiveness in 2018 is shown in Table 2.

Tab. 2 - Competitiveness of the Slovak Republic in 2018. Source: The Global Competitiveness Report (2018).

\begin{tabular}{|l|l|l|}
\hline \multirow{2}{*}{ Pillars of competitiveness } & \multicolumn{2}{|l|}{ Rating by Global Competitiveness Index 4.0 - year 2018 } \\
\cline { 2 - 3 } & Ranking & Achieved score \\
\hline Institutions & 55 & 56.4 \\
\hline Infrastructure & 33 & 77.6 \\
\hline Macroeconomic environment & 32 & 99.9 \\
\hline Market size & 60 & 57.7 \\
\hline Technological readiness & 35 & 67.8 \\
\hline Health and primary education & 57 & 84.0 \\
\hline Higher education and training & 48 & 68.6 \\
\hline Goods market efficiency & 78 & 55.0 \\
\hline Labour market efficiency & 58 & 60.2 \\
\hline Financial market development & 54 & 63.7 \\
\hline Business sophistication & 45 & 64.5 \\
\hline
\end{tabular}




\begin{tabular}{|l|l|l|}
\hline Innovation & 43 & 46.6 \\
\hline Resulting values & 41 & $\mathbf{6 7 . 0}$ \\
\hline
\end{tabular}

The United States of America was placed first, followed by Singapore and Germany. The Czech Republic (29th) ranked best among the V4 countries. Poland took the 37th position and Hungary ranked 48th. The position of the Slovak Republic has worsened slightly, despite the fact that the competitiveness score slightly improved. However, in the ranking, the Slovak Republic was overtaken by countries that have improved the conditions for entrepreneurship and economic growth more than the Slovak Republic. Macroeconomic stability, health of the population and the overall level of infrastructure are evaluated positively.

As for the world's most problematic areas, the World Bank considers the indicators Institutions and Innovation. There are only a few countries with strong innovativeness in the world, e.g. Germany, USA and Switzerland. The global average score in the innovation pillar is 36, which is the lowest score in 12 pillars. For 77 of the 140 economies under study, the ability to innovate is the weakest pillar. More than $2 / 3$ of the countries have a score below 50.28 . The adoption of 4IRs is a crucial factor for competitiveness and only those economies that recognize its importance will be able to expand opportunities for their people. Above all, we consider two pillars, higher education and training and innovation as very important ones, in which the Slovak Republic has achieved a relatively low rating compared to other countries. The long-term disadvantages are the efficiency of the judiciary or electronization.

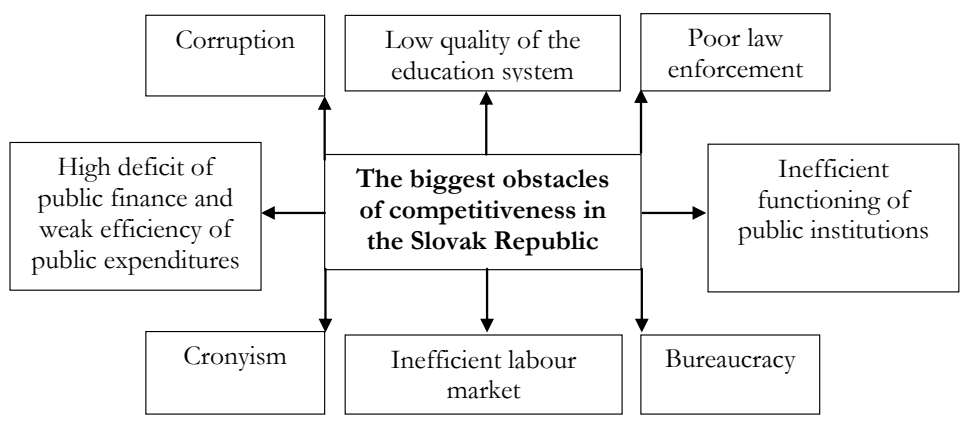

Fig. 3 - The biggest obstacles that decrease the level of competitiveness in the Slovak Republic. Source: own research

The Slovak Republic was perceived as the state applingreforms, but from 2004, the entrepreneurs did not obtain reforms that would significantly improve business conditions. The biggest obstacles that decrease the level of competitiveness in the Slovak Republic are in Figure 3.

All market participants (especially companies) in the Slovak Republic are in the space which is more and more open and where are many companies that have international, global or euro strategies. This fact results in big a competition of all participants at all levels (e.g. national, resp. international, sector, company). The Slovak Republic needs to realize many actions that can cause the increase in competitiveness as a whole and it is very important to measure the actual situation periodically, because only the permanent focus on improvements can ensure the Slovak 
Republic increasing in the competitiveness ranking. It is clear that competitiveness is influenced by many factors these days. However, the crucial factor is, of course, innovation. Innovation is a challenge for every company, but nowadays, it is not the challenge only, but also the necessity.

It is logical that without innovation a company is only in the reactive position, while with innovation the company gains the proactive position, which then results in higher competitiveness. The SWOT analysis of enterprises competitiveness in the Slovak Republic is graphically displayed Table 3.

Tab. 3 - SWOT analysis of enterprise competitiveness in the Slovak Republic. Source: own research

\begin{tabular}{|c|c|}
\hline Strengths & Weaknesses \\
\hline $\begin{array}{l}\text { - Stability of macroeconomic indicators } \\
\text { - High motivation for performance by the } \\
\text { owners } \\
\text { - Operation of SMEs making use of their } \\
\text { biggest advantages such as the experience } \\
\text { with local business, respectively a strong } \\
\text { adaptability to client's requirements }\end{array}$ & $\begin{array}{l}\text { - Orientation toward production, in which } \\
\text { high-energy consumption is necessary } \\
\text { - Scheme of assistance for enterprises is } \\
\text { poor } \\
\text { - Readiness for Industry } 4.0 \text { is weak } \\
\text { - Insufficient examples of successful } \\
\text { persons in the sphere of management and } \\
\text { marketing } \\
\text { - Predominance of classical mass } \\
\text { production } \\
\text { - Poor financial security of the enterprises } \\
\text { in the area of law and legislation }\end{array}$ \\
\hline Opportunities & Threats \\
\hline $\begin{array}{l}\text { - Better exploitation of assistance for } \\
\text { enterprises } \\
\text { - Wider coverage of the EU common } \\
\text { market } \\
\text { - Purposeful cooperation between } \\
\text { enterprises in the area of global } \\
\text { integration } \\
\text { - Closer connection between enterprises } \\
\text { and other institutions in the area of } \\
\text { R \& D with a strong emphasis on } \\
\text { technological innovation }\end{array}$ & $\begin{array}{l}\text { - Decrease in the factors that are crucial } \\
\text { for the application of Industry } 4.0 \text { caused } \\
\text { by lack of capital } \\
\text { - Consequences of the unfavourable } \\
\text { development of economic cycles } \\
\text { - Competition from enterprises of other } \\
\text { countries } \\
\text { - Highly skilled workers leaving to go } \\
\text { abroad }\end{array}$ \\
\hline
\end{tabular}

Based on a research study of Research Department of the National Bank of Slovakia, the most important factors of Slovak enterprises competitiveness were identified, shown in Table 4, while factors of competitiveness are arranged according to their importance, from the most important to the least. 
Tab. 4 - The most important factors of Slovak enterprises competitiveness. Source: own research

\begin{tabular}{|l|l|}
\hline Intradepartmental factors & $\begin{array}{l}\text { - management professionalism } \\
\text { - quality of enterprise management } \\
\text { - focus on costs reducing (production price) } \\
\text { - efficiency of business management } \\
\text { - range of communication technologies utilization }\end{array}$ \\
\hline Branch factors & $\begin{array}{l}\text { - customer requirements } \\
\text { - availability of qualified and experienced managers } \\
\text { - } \text { nature of competitive advantage } \\
\text { - existence of developed customer industries }\end{array}$ \\
\hline Macro-level factors & $\begin{array}{l}\text { - EU membership and euro utilization } \\
\text { - energy costs }\end{array}$ \\
\hline
\end{tabular}

Comparing our research with other research articles in this area, we can state that Kalusova \& Skriniar (2018) have also identified innovation as one of the biggest problems of Slovak competitiveness at the international level and also as the crucial factor that decreases the Slovak Republic's ranking in the GCI index evaluation. It is obvious that all adopted steps in the Slovak Republic that were supposed to support innovation have not been as successful as they can be, and it remains a challenge for the government (with parliamentary elections having been held in spring 2019) to adopt enhanced or additional support measures that will improve the innovation level as a whole.

Our results agree with research published by Necadova \& Soukup (2013), who indicate that the crucial problematic entrepreneurship factors are the inefficiency of government bureaucracy, the extent of corruption, political instability, as well as a lack of infrastructure or its deterioration. These factors are outlined in a study by Necadova \& Soukup (2013) as well as in a study of ours from this year, both of which demonstrate that in this context insufficiently effective measures have been taken to eliminate these negative impacts. Slovakia has long been censured for these shortcomings by the EU, another factor which reduces Slovakia's ranking.

Gavurova et al. (2017) has stated that in the Slovak Republic strong regional disparities remain, a phenomenon that the EU indicates it wants to eliminate. Our research corroborates this evidence showing disparities among regions, e.g. the weaknesses shown in the SWOT analysis showing the predominance of classical mass production, i.e. regarding the automotive industry in particular, which remains dominant in the Slovak Republic. The problem here is that all 4 automotive producers are located in Western Slovakia (Volkswagen Slovakia - Bratislava, Kia Motors Slovakia - Zilina, Groupe PSA Slovakia - Trnava, Jaguar Land Rover Slovakia - Nitra). 
Other regions do not have as many strong employers, a factor which is very important for young people who do not wish to remain in Eastern or Middle Slovakia, thus they migrate to Western Slovakia, where a higher life standard is more easily achieved. We also agree with Gavurova et al. (2017) regarding the fact that this problem will not be alleviated until the highway crossing the country from Bratislava to Kosice is built.

If the position of the Slovak Republic is analyzed in the context of the EU, we have to agree with the research published by Pelle \& Vegh (2017) which points out the serious divide within the EU regarding competition, competitiveness and entrepreneurship. If we compare, e.g. the adoption of Industry 4.0 in Germany and in the Slovak Republic, it is logical that the Slovak Republic has not yet developed such a strong basis, e.g. financial support, a situation which results in a lag in the rate of development in small EU countries.

Hvizdakova \& Urbancikova (2014) have indicated how the economies of the Czech Republic, Greece, Slovakia, Poland and Lithuania can be grouped as "moderate innovators," a category which does not quite correspond with our research, as the Slovak Republic has a major problem with the level of innovation, as indicated previously in the present article. Nevertheless, if the issue is considered more carefully, our results concur with that of the research of Hvizdakova \& Urbancikova (2014), who place the Slovak Republic within the third group of EU countries, with the fourth group of consisting only of the "catching-up countries" of Romania, Latvia and Bulgaria.

Bondareva \& Tomcik (2015) summarize the most important barriers of the Slovak Republic, which include a low quality of public institutions, a significant level of corruption, and low innovation activity. This corresponds with our research, as we have also identified these barriers as most significant. Our research along with that of Bondareva \& Tomcik (2015) has indicated these barriers as the key factors that must be improved during the next few years.

Palascakova et al. (2014) note that the Slovak Republic is a strongly globalized country, i.e. ranking among the top 15 most globalized countries. Our results agrees with this, as we report that among the biggest opportunities for the Slovak Republic can be listed purposeful cooperation among business enterprises in the area of global integration, which is very strong in the Slovak Republic.

Habanik et al. (2016) have noted that among the priorities that have to be supported in the Slovak Republic are research and innovation, information and communication technologies, and SME competitiveness. Our results correspond with this research, as we have also noted these factors as the priorities for the Slovak government in the next years.

\section{CONCLUSION}

Competitiveness in the field of entrepreneurship is a topic of great relevance today, i.e. the subject of discussions at the national as well as international level, and especially within the EU context. Despite the fact that more and more authors have become concerned with the analysis of competitiveness, so far there is no uniform definition of competitiveness has emerged in the literature due to the fact that it is possible to consider competitiveness from a number of varying perspectives. 
Significant factors that increase competitiveness at the enterprise level include the application of modern methods in management and marketing, increasing labour productivity, along with the application of modern research, science and technology into practice. Providing services include better work organization, the ability to implement innovations in a timely manner, enhancing the use of human resources, increasing the value of human capital for employees, improving the effectiveness of motivational activities, and more effective work with prospectively more productive and talented employees. It can be said that despite the significant changes that have occurred in recent years in the field of competitiveness in Slovakia, several problems remain that are very important to face. In this article, we have seen that despite the increasing position of the Slovak Republic in competitiveness metrics, many areas remain in which the Slovak Republic continues to suffer major long-term competitive disadvantages which must be alleviated or eliminated in concrete ways.

A stronger rate of growth in the Slovak Republic is hindered by the chronic problems within the business environment, especially in the quality of public institutions. Slovakia has a lot to catch up on regarding the strengthening of the independence of the judiciary, enhancing law enforcement, e.g. battling corruption, as well as reducing the administrative burden of doing business.

A significant weakness of Slovakia is its low innovation capacity, which is related to the quality of its scientific and research institutions, the limited level of government cooperation with companies, as well as low expenditure on research and development. In supporting the growth of its competitiveness in the coming years, many huge challenges remain for Slovakia, i.e. addressing the lack of qualified staff, alleviating the high administrative burden on businesses, meeting the current and future challenges of business digitization, improving recruitment initiatives, lowering dismissal costs, as well as reforming education and public services.

\section{Acknowledgments}

The research for this article was funded by implementation of the grant project KEGA 030TUKE-4/2017 Implementation of innovative instruments for increasing the quality of higher education in the 5.2.52 Industrial Engineering field of study.

\section{References}

1. Adamkiewicz-Drwiłło, H. G. (2002). Uwarunko-wania konkurencyjności prz̨edsiebbiorstwa. Warszawa: Wydawnictwo Naukowe PWN.

2. Altomonte, C., Aquilante, T., \& Ottaviano, G.I.P. (2012). The Triggers of Competitiveness. The EFIGE Cross-Country Report. Brussels: The Bruegel Blueprint Series. Retrieved April 2, 2019, from https://bruegel.org/wp-content/uploads/imported/publications/Blueprint_ XVII_web.pdf

3. Ambastha, A., \& Momaya, K. (2004). Competitiveness of Firms: Review of Theory, Frameworks and Models. Singapore Management Review, 26 (1), 45-61.

4. Barker T., \& Köhler J. (1998). Environmental Policy and Competitiveness. Environmental Policy Research Briefs, 6 (10), 1-12.

5. Bobba F., Langer W., \& Pous J. W. (1971). Bericht über die Wettbewerbsfäbigkeit der Europäischen Gemeinschaft, Brussels. 
6. Bondareva, I., \& Tomcik, R. (2015). Comparison of economic development of the Slovak Republic and the Czech Republic based on the global competitiveness index. Scientific Papers of the University of Pardubice, Series D: Faculty of Economics and Administration, 22 (33), 6-16.

7. Buckley P. J., Pass C. L., \& Prescott K. (1988). Measures of International Competitiveness: A Critical Survey. Journal of Marketing Management, 4 (2), 175-200. http://dx.doi.org/10.1080/ 0267257X.1988.9964068

8. Crecente-Romero, F., Giménez-Baldazo, M., \& Val-Núnez, M. T. (2019). Competitiveness and entrepreneurship rate in Europe during the economic recovery phase, 2012-2016. International Entrepreneurship and Management Journal, 15 (2), 455-470. https://doi.org/10.1007/ s11365-019-00572-x

9. D’Andrea Tyson L. (1992). Who's Bashing Whom: Trade Conflict in High Technology Industries. Washington: Institute for International Economics.

10. Fifekova, E., Nezinsky, E., \& Nemcova, E. (2019). Global Competitiveness of Europe: A Robust Assessment. Danube, 9 (4), 245-260. https://doi.org/10.2478/danb-2018-0015

11. Flejterski, S. (1984). Istota i mierzenie konkurencyjności międzynarodowej. Gospodarka Planowa. Miesięcznike poświecony problemom planowania i rozwoju gospodarki narodowej, 39 (9), 390-394.

12. Gavurova, B., Soltes, M., \& Kovac, V. (2017). Application of cluster analysis in process of competitiveness modelling of the Slovak Republic regions. Transformations in Business and Economics, 16 (3), 129-147.

13. Gkypali, A., Kounetas, K., \& Tsekouras, K. (2019). European countries’ competitiveness and productive performance evolution: unraveling the complexity in a heterogeneity context. Journal of Evolutionary Economics, 29 (2), 665-695. https://doi.org/10.1007/s00191018-0589-x

14. Gulev R. E., \& Dukaric, G. (2010). Exploring the Connectivity between Work Inclinations and Country Competitiveness Levels: A Cross-country Analysis. International Journal of Sustainable Economy. 2 (2), 127-143. http://dx.doi.org/10.1504/IJSE.2010.030755

15. Habanik, J., Kordos, M., \& Hostak, P. (2016). Competitiveness of Slovak economy and regional development policies. Journal of International Studies, 9 (1), 144-155. https://doi. org/10.14254/2071-8330.2016/9-1/10

16. Hickman, B. G. (1992). International Productivity and Competitiveness. New York: Oxford University Press.

17. Hvizdakova, I., \& Urbancikova, N. (2014). The level of social capital, innovation and competitiveness in the countries of the European Union (EU). European spatial research and policy, 21 (1), 123-136. https://doi.org/10.2478/esrp-2014-0009

18. Kalusova, L., \& Skriniar, P. (2018). Competitiveness of the Visegrad group countries measured by Global competitiveness index. Jihlava: 10th Annual International Scientific Conference on Competition. 
19. European Competitiveness and Industry. (2017). Benchamrking 2017. Brussels: European Round Table of Industrialists. Retrieved March 12, 2019, from http://ert-industrybenchmarking.eu/wp-content/uploads/2017/12/ERT-Stats_Benchmarking-2017_4web_21 122017hyperlinksgroupedBookmarks.pdf

20. Krugman, P. (1995). Growing World Trade: Causes and consequences. Brookings Papers on Economic Activity, 26 (1), 327-377. http://dx.doi.org/10.1093/0198293607.003.0005

21. Kulikov, G. (2000). Japonskij menedzhment i teorija mezhdunarodnoj konkurentosposobnosti. In Ekonomika. Moscow.

22. Malega, P. (2017). Small and Medium Enterprises in the Slovak Republic: Status and Competitiveness of SMEs in the Global Markets and Possibilities of Optimization. In Optimal Management Strategies in Small and Medium Enterprises. (pp. 102-124), IGI Global, Hershey.

23. Malega, P. (2018). Competitiveness of Slovak SMEs in the context of competitiveness of the Slovak Rrepublic. Interdisciplinarity in Theory and Practice, 6 (15), 1-6.

24. Mihok, J., Malega, P., \& Nascakova, J. (2006). Competitiveness as a result of effectiveness. Vedecké listy, 2 (3), 75-80.

25. Necadova, M., \& Soukup, J. (2013). The controversial concept of national competitiveness and the results of the Visegrad group in international rankings of competitiveness (20072012), Politicka ekonomie, 61 (5), 583-604. https://doi.org/10.18267/j.polek.918

26. Palascakova, D., Kyrychuk, A., \& Rohacova, T. (2014). Globalisation processes and their impact on the competitiveness of the Slovak Republic. Actual Problems of Economics, 152 (2), $47-52$.

27. Pelle, A., \& Vegh, M. Z. (2017). Entrepreneurship and Competitiveness in the EU Member States, with Special Regard to the Visegrad Countries. Problemy zarzadzania-Management issues, 15 (1), 13-32. https://doi.org/10.7172/1644-9584.65.1

28. Porter M.E. (1990). The Competitive Advantage of Nations. New York: The Free Press.

29. Porter, M., Ketels, C., \& Delgado, M. (2008). The Microeconomic Foundations of Prosperity: Findings from the Business Competitiveness Index. The Global Competitiveness Report, 1-31, WEF, Geneva.

30. Rapkin, D. P., \& Avery, W. P. (1995). National competitiveness in a global economy. Boulder: Lynne Rienner Pub.

31. Salas-Velasco, M. (2019). Competitiveness and Production Efficiency across OECD Countries. Competitiveness Review, 29 (2), 160-180. https://doi.org/10.1108/CR-07-2017-0043

32. Scott B. R., \& Lodge G. C. (1985). US Competitiveness in the World Economy. Boston: Harvard Business School Press.

33. Straka, M., Trebuna, P., Rosova, A., Malindzakova, M., \& Makysova, H. (2016). Simulation of the process for production of plastics films as a way to increase the competitiveness of the company. Przemysl chemiczny, 95 (1), 37-41. https://doi.org/10.15199/62.2016.1.3

34. The Global Competitiveness Report 2018. (2018). Available at: http://reports.weforum.org/ global-competitiveness-report-2018/ 
35. Zavadsky, J., Korenkova, V., Zavadska, Z., Tucek, D., \& Kadarova, J. (2019). Competences in the quality management system evaluation based on the most worldwide used key performance indicators. Quality - Access to Success, 20 (169),

\section{Contact information}

Ing. Peter Malega, PhD.

Technical University of Kosice

Faculty of Mechanical Engineering

Institute of Management, Industrial and Digital Engineering

Slovak Republic

E-mail:peter.malega@tuke.sk.

doc. Ing. Vladimir Rudy, PhD.

Technical University of Kosice

Faculty of Mechanical Engineering

Institute of Management, Industrial and Digital Engineering

E-mail:vladimir.rudy@tuke.sk

Ing. Juraj Kovac, PhD.

Technical University of Kosice

Faculty of Mechanical Engineering

Institute of Management, Industrial and Digital Engineering

Slovak Republic

E-mail:juraj.kovac@tuke.sk.

prof. Ing. Jozef Kovac, CSc.

Technical University of Kosice

Faculty of Mechanical Engineering

Institute of Management, Industrial and Digital Engineering

Slovak Republic

E-mail:jozef.kovac@tuke.sk 